\title{
Missionaries as Communicators of Foreign Cultures
}

\section{Helander, Eila Marjatta}

2017

Helander , E M \& Räsänen , A J A 2017 , ' Missionaries as Communicators of Foreign

Cultures ' , Exchange , vol. 46 , no. 3 , pp. 285-305 . https://doi.org/10.1163/1572543X-12341448

http://hdl.handle.net/10138/311513

https://doi.org/10.1163/1572543X-12341448

unspecified

acceptedVersion

Downloaded from Helda, University of Helsinki institutional repository.

This is an electronic reprint of the original article.

This reprint may differ from the original in pagination and typographic detail.

Please cite the original version. 


\title{
Missionaries as Communicators of Foreign Cultures
}

\author{
Antti Räsänen \\ Professor of Religious Education, University of Helsinki \\ E-mail: antti.rasanen@helsinki.fi \\ Eila Helander \\ Professor emerita in Church and Social Studies, University of Helsinki \\ E-mail: eila.helander@helsinki.fi
}

\begin{abstract}
This article examines the writings of Finnish missionaries: what the missionaries wrote about local people and cultures and how the content of their writings changed during the latter part of the 20th century, which was a period of major political and cultural change in the countries where the missionaries worked. The data consists of 526 writings published in the major Finnish mission journal Suomen

Lähetyssanomat during the years 1946-1989. The primary methodological approach is quantitative, and the data is mainly analysed in a descriptive manner. Statistical tests are utilized to show the association between independent and dependent variables. The results are interpreted with the help of the concept of otherness. Missionaries' writings reveal a more positive attitude towards local people than local cultures, but during the study period a change towards a more positive attitude to culture can be detected. The longer the history of Finnish missions in a particular region, the more positive the missionaries' attitudes towards local people are. During the study period, the problem-oriented descriptions of cultures shift to solution-oriented descriptions. These changes indicate efforts towards a positive interpretation of otherness. The study reveals the possibilities that quantitative analysis may open up for mission studies.
\end{abstract}

Keywords: Missionaries, discourse, culture, change, missiology

\section{Introduction}

In countries like Finland without a colonial history, missionaries functioned for a long time as the sole channel of information on non-Western peoples. When Finnish missionaries were on furlough in their homeland, they frequently visited parishes and schools, telling about their work in foreign cultures. For example, in the 1970s, they reached approximately 25 percent of the compulsory education-aged students. Thus, missionaries are rightly called the pioneers of intercultural education in Finland. ${ }^{1}$

The Finnish Missionary Society (FMS) was founded in 1859. In the same year, the FMS started to publish its own mission journal, Suomen Lähetyssanomat (Finnish Mission Journal - FMJ). Even though the writings of the mission journal were targeted primarily at those interested in missions, the mediated views and depictions also reached wider circles. Only in the latter part of the 20th

\footnotetext{
* Antti Räsänen (b. 1961) is Professor of Religious Education at the University of Helsinki. He has focused on religious development in adulthood and issues of religiousness during the life cycle. Later the perspective changed to studying youth and childhood spirituality. His third research area is religiousness among Church members and contexts of society, including missiology. His current interest is in stereotypes and meta-stereotypes between and within different religious groups.

Eila Helander (b. 1946) is Professor emerita in Church and Social Studies at the University of Helsinki. Her research interests are women in religion, partnership in mission and churches in today's European societies. Publications: 'Women Teaching Women: The Impact of Gender and Religion on Training Teachers in Colonial Africa', Temenos 42/2 (2006), 65-78. With Niwagila W. B., Partnership and Power. A Quest for Reconstruction in Mission, Makumira Publication 7, Erlangen: Verlag der Evangelisch-Lutherischen Mission 1996.

${ }^{1}$ Eila Helander and Antti Räsänen, 'Lähetystyöntekijät - kansainvälisyyskasvatuksen pioneerit', in: Riku Hämäläinen and Heikki Pesonen (eds.), Kohtaamisia: Kirjoituksia uskonnosta, arjesta ja monikulttuurisuudesta, Uskontotiede 16, Helsinki: Helsingin yliopisto 2015, 291-292.
} 
century did the number of other information channels on foreign cultures and people expand. In the 1960s and 1970s, growing information technology and tourism increased the Finns' possibilities to receive information and establish contacts in different parts of the world, widening their views of developing countries and the perception of global responsibility.

The latter part of the 20th century is an especially interesting period for mission studies. This was a time of major political transition in the countries where Western missionaries worked. These changes also brought with them attitudinal shifts in the cultural sphere, not only in the new independent nations and their churches but also in the missionizing Western churches. Understandings of missions and Christianity in relation to non-Western cultures and people went through major changes. For example, new theological approaches implied that missionaries also needed expertise in cross-cultural relations and understanding. ${ }^{2} \mathrm{We}$ presume that the consequences of these changes can be detected in missionary writings and how missionaries depicted the cultures and people they worked with.

In this article, we will focus on the writings of Finnish missionaries in the main Finnish mission journal Suomen Lähetyssanomat during the second half of the 20th century: what missionaries told about their work and how they depicted the cultures they visited and the people they encountered and worked with. We also aim to describe how the missionary discourse changed.

\section{Previous Studies and Theoretical Approaches}

Missionary writings can be grouped into three categories: personal documents like diaries, letters and official reports to mission organizations; varied descriptions of their work, such as articles in missionary journals; and fictive literature. Missionaries' letters, reports and other documents produced by them have been used as central sources in mission and cultural histories. The wide range of topics, from religion and people to nature and the climate and music, has even interested scholars from different fields outside mission studies. ${ }^{3}$

The views and attitudes of missionaries in the latter part of the 20th century, reflected in their writings, have evoked the interest of international scholars. ${ }^{4}$ But while differences in individual missionaries' thinking have been noted, few studies ${ }^{5}$ have focused on how discourses have changed during that particular period.

The type of picture that missionaries have communicated through their writings of Africans and their culture has also interested Finnish scholars, but their focus has been mainly on the first half of the 20th century. ${ }^{6}$ In his analysis on missionaries' circular letters, Pesonen also discusses how their

\footnotetext{
${ }^{2}$ Paul G. Hiebert, Anthropological Insights for Missionaries. Michigan: Baker Book House 1985; James M. Phillips, \& Robert T. Cooke, Toward the Twenty-First Century in Christian Mission. Michigan: William B. Eerdmans Publishing Company 1993; Timothy Yates, Christian Mission in the Twentieth Century. Cambridge: Cambridge University Press 1994.

${ }^{3}$ See e.g. Georgine H. Endfield and David J. Nash, 'Missionaries and Morals: Climatic Discourse in NineteenthCentury Central Southern Africa', Annuals of the Association of American Geographers 92/4 (2002), 727-742; Denis Lineham, 'Irish Empire: Assembling the Geographical Imagination of Irish Missionaries in Africa', Cultural Geographies 21/3 (2014), 429-447; Michael Schubert, 'The German nation and the black Other: Social Darwinism and the Cultural Mission in German Colonial Discourse', Patterns of Prejudice 45/5 (2011), 399-416; Stig-Magnus Thorsén, 'Three Swedish Missionaries: Images of Music in Southern Africa', STM Online 8 (2005).

${ }^{4}$ Justin Livingstone, 'Ambivalent Imperialism: The Missionary Rhetoric of Robert Boyd', Literature \& Theology $23 / 2$ (2009), 165-191; Friedegard Tomasetti, 'Traditional Religion: Some Perceptions by Lutheran Missionaries in German New Guinea', The Journal of Religious History 22/2 (1998), 183-199.

${ }^{5}$ E.g. Albert de Jong, 'Africans Viewed in Missionary Mirror: Shifts in the 'Black-White' Thinking of Dutch Missionaries on Africans and Their Culture in East Africa 1945-1965', Exchange 30/1 (2001), 49-77.

${ }^{6}$ Anna-Leena Schulz, Afrikkalaisista ihmisistä annettu kuva Suomen Lähetyssanomissa vuosina 1869-1900. Uskontotieteen julkaisematon pro gradu -tutkielma, Helsingin yliopisto: Uskontotieteen laitos 1988; Kati Kemppainen, Suomalaisten suhteet anglikaaneihin ja katolilaisiin Lounais-Afrikassa 1919-1937. Suomen kirkkohistoriallisen seuran
} 
presumed recipients can be distinguished by the ways in which the letters have been written, and how this in turn has influenced what missionaries tell about and how they do it. Rowbotham, in turn, writes how British female missionaries writings strengthened stereotypes, and even prepared the ground for white and British female superiority. ${ }^{7}$

In the Finnish scholarship, Löytty mentions that missionary discourse has changed, but even though his perspective covers a long span of time, including the latter part of the 20th century, what this change entails is left more or less to the reader to discover. In her analysis on the journal Suomen Lähetyssanomat, Helander briefly discusses changes in missionary writing. ${ }^{8}$ But thus far, the approach has by and large been qualitative, which has limited the number of analysed texts. There is a need for quantitative analysis of missionary writings to get a broader picture of eventual changes over a longer period of time. This article has taken up this challenge.

Writings published by mission organizations passed through a certain control system, and they can be seen as a form of institutionalized discourse. A mission discourse, like all knowledge, produces information, which defines values and creates hierarchies for those it describes. ${ }^{9}$ The dualistic perspective 'we and others' characterizes colonial and post-colonial discourse. ${ }^{10}$ Like Cleall describes:

Throughout their copious published writings, missionaries conveyed such horrors, hopes and anxieties to the imperial metropole producing a much-consumed strand of colonial discourse that allowed the British public to imagine Indians, Africans and other peoples of empire and the 'distant countries' they inhabited. These constructions were not, of course, all about otherness, but also about imagining the self, as the author (and readers) of such literature sought to make sense of their own identities in colonial context. ${ }^{11}$

Even though the writings of Finnish missionaries have shared the cultural attitudes of their times, there are also noteworthy discursive differences compared to the colonial discourse. Finnish missionaries did not represent a colonial power, but compared with to those they wrote about, they were privileged in many ways. Colonial discourse justified hierarchical colonial relationships by focusing on producing differences, whereas in the mission discourse one can discover, at least as an ideal, the concept of Christians who are equal before their creator. Nevertheless, the concept of otherness is a useful tool to also analyse Finnish missionary writings. ${ }^{12}$

We understand by otherness a state in which the individual or group is in relationship with a group that possesses the right to define otherness. Otherness is always based on the difference between the self and the other. Most often these are perceptions, beliefs and assessments of the foreign. They do not necessarily describe what the other people actually are or what kind of characteristics they have, but what I am myself, and what my vision of the world is. ${ }^{13}$

\footnotetext{
julkaisuja 180, Helsinki: Suomen kirkkohistoriallinen seura 1998; Kari Miettinen, On the Way to Whiteness. Christianization, Conflict and Change in Colonial Ovamboland 1910-1965, Helsinki: SKS 2005; Olli Löytty, Ambomaamme: Suomalaisen lähetyskirjallisuuden me ja muut, Tampere: Vastapaino 2006;

${ }^{7}$ Heikki Pesonen, 'Kaksi kotimaata. Suomen Lähetysseuran Afrikan lähettien kiertokirjeiden retoriikkaa', in: Tuula Sakaranaho and Heikki Pesonen (eds.), Uskonto, julkisuus ja muuttuva yhteiskunta, Helsinki: Helsinki University Press 2002, 99-131; Judith Rowbotham, 'Hear an Indian Sister's Plea: Reporting the Work of 19th-century British Female Missionaries', Women's Studies International Forum 21/3 (1998), 247-261.

${ }^{8}$ Eila Helander, 'Lähetyssanomat kulttuurikuvien luojana', in: Sari Dhima (ed.), Kirkko, taide ja viestintä, Helsinki:

Societas Historiae Ecclesiasticae Fennica 2005, 279-287.

${ }^{9}$ Löytty, Ambomaamme, 121.

${ }^{10}$ Schubert, 399-416; Stuart Hall, 'Identiteetti', in: Mikko Lehtonen and Juha Herkman (eds.), Identiteetti, Tampere: Vastapaino 1999; Esme Cleall, Missionary Discourse of Difference: Negotiating Otherness in the British Empire 18401900, United Kingdom: Palgrave Macmillan 2012.

${ }^{11}$ Cleall, 2.

${ }^{12}$ See e.g. Löytty, Ambomaamme.

${ }^{13}$ Marjo Kaartinen, Neekerikammo: Kirjoituksia vieraan pelosta, Turun yliopisto, Turku: K \& H 2004, 21-24.
} 
Löytty points out that otherness is not only a difference, but also a power relationship in which the other is understood as inferior and having a lower status. In Löytty's view, on one hand the recognition of otherness has made it possible to reveal and dissolve power hierarchies, and increase equality and parity. On the other hand, stressing otherness (in a wrong manner and/or inappropriate context) can refer to practices that highlight differences and accent strong positive and negative esteem between us and the other. ${ }^{14}$

All information is communicated and stories are told in a certain socio-cultural situation and from a particular point of view. Cultural patterns influence how people perceive their experiences and surroundings and how and what they tell about them. ${ }^{15}$ Consequently, mission discourse is also ethnocentric with a value tendency: norms and values propagated by missionaries are determined by their own culture. ${ }^{16}$

In this article, we ask how Finnish missionaries reported about local people and their cultures, and how their reporting and attitudes towards local people and cultures shifted from the 1940s to the 1980s. In addition, we analyse possible explanatory variables such as gender and the geographical areas where missionaries worked. The results are interpreted with the help of the concept of otherness.

\section{Data and Method}

In order to answer our research question, we utilize both qualitative and quantitative data. The research data consists of news, features and stories written by Finnish missionaries in the mission journal Suomen Lähetyssanomat. The data is comprised of 526 writings from the years 1946-1989. Figure 1 illustrates the number of writings in each decade of the research period. Note that the 1940s includes only four years (1946-1949). However, it seemed rational to name the category 'The Forties' even though it does not cover the whole decade.

FIGURE 1. Quantity of data according to decade of publishing.

\footnotetext{
${ }^{14}$ Olli Löytty, 'Toiseus', in: Laura Huttunen and Olli Löytty and Anna Rastas (eds.), Suomalainen vieraskirja. Kuinka käsitellä monikulttuurisuutta?, Tampere: Vastapaino 2005, 161-189.

${ }^{15}$ Eila Helander, 'Source Criticism and Cultural Models. Consulting Life Histories of Women Missionaries', in: Tore Ahlbäck (ed.), Approaching Religion, volume 2, Åbo (Finland): The Donner Institute for Research in Religious and Cultural History 1999; James A. Holstein and Jaber F. Gubrium, 'Phenomenology, Ethnometodology and Interpretive Practice', in: Norman K. Denzin and Yvonna S. Lincoln (eds.), Handbook of Qualitative Research, Thousand Oaks: Sage 1994, 262-272; Dorothy Holland, and Naomi Quinn, Cultural Models in Language and Thought, Cambridge: Cambridge University Press 1987.

${ }^{16}$ Löytty, Ambomaamme, 102, 147, 268-269.
} 


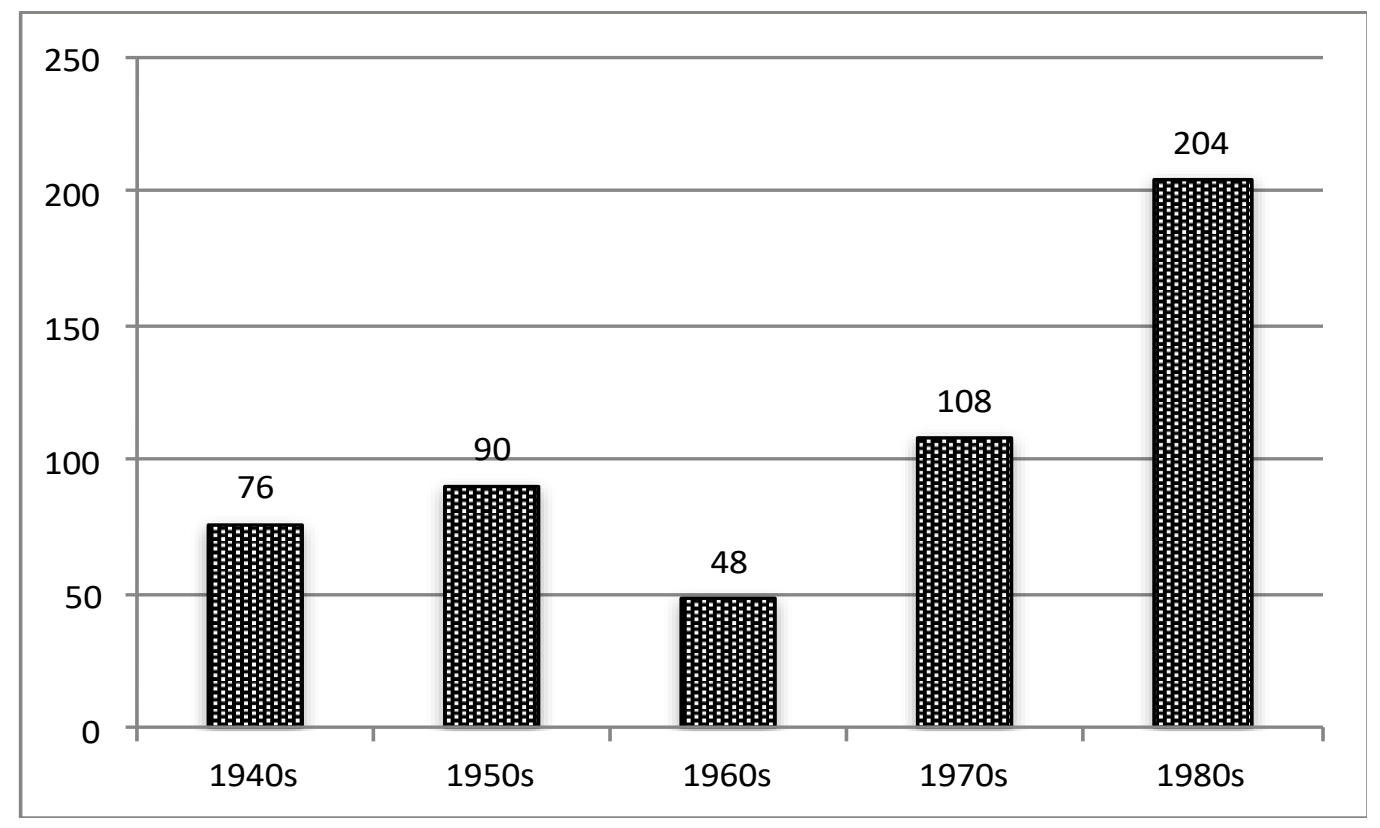

Overall, the average number of writings per year was 12.4 texts. There were 22 years in which the number of texts was under the average. The variation between the years was quite large, for the missionaries produced very few texts in the end of the 1960s $(1965$ and $1967 n=3 ; 1969 n=1)$, while, on the other hand, the first half of the 1980s was extremely productive $(1980 \mathrm{n}=24 ; 1983 \mathrm{n}$ $=32 ; 1982$ and $1985 \mathrm{n}=22)$.

Half of the writings $(\mathrm{n}=268 ; 51 \%)$ were feature-style texts describing local cultures. Some texts were descriptions of the missionaries' own work $(\mathrm{n}=75 ; 14 \%)$; in these cases, the local culture and people were in the background. There were some letters by missionaries $(n=48 ; 9 \%)$, and only a couple of news $(n=9 ; 2 \%)$ were reported. Quite a number of writings were difficult to classify or represented many styles and forms $(n=126 ; 24 \%)$. More than two thirds of the texts $(n=362 ; 69$ $\%)$ were written by women.

Data analysis was executed in the following manner. We approached a qualitative text corpus, consisting of all 526 writings. This data was qualitative by nature. In the beginning of the analysis, the texts were coded into a quantitatively analysable form which produced 25 variables. In addition to quantitative data, we report quotations from the original writings of Finnish missionaries, which are used to illustrate the details that the numerical data cannot reach. The role of quotations is complementary and descriptive, not verificatory.

The focus is on what and how missionaries have written about the people and cultures they worked with, as well as their countries. As noted above, the chosen period of study coincides with the political independence of many of these countries. Therefore, in addition to religious leaders, even political leaders and persons in positions of power were observed. Cultural contexts were mapped out by counting to what extent the writings dealt with nature, local customs, life conditions, social and societal (political) questions, and the exercising of religion. By looking at writings about the different forms of missionary work, the aim was to map cultural encounters and missionaries' efforts to have intercultural influence.

Since quantification is already a form of interpretation, how can we guarantee that we do not lose the original character of the writings? Three principles were applied to ensure the reliability: first, the same criteria (= the same codes) were utilized for every text and the coder created new categories for individual variables when it was reasonable. Secondly, the qualitative nature is still visible in the quantitative variables. For example, Likert-type scales like negative/neutral/positive insights were used to measure the quality of writings, not only their quantity. And finally, the coder 
was a scholar in comparative religion and a previous missionary herself, which very likely helped her to create appropriate, coherent and reliable variables of the data.

From our own methodological perspective, we considered it necessary to quantify the large set of data in order to get it into an analysable format. We perceive - like the Finnish scholars Alasuutari, and Eskola and Suoranta - qualitative and quantitative analysis to be a continuum, not exclusionary dichotomies. In addition to this continuum of quantitative and qualitative analysis, one can talk about the methodicalness of qualitative data. Analysis can be understood as a continuum, which on one end has an impressionistic character and on the other end an intensively systematic aspect. ${ }^{17}$

The quantitative data was mainly analysed in a descriptive manner. We used cross-tabulation with two or more variables and deviations and percentage-proportions to describe single variables. Statistical tests (= Student's t-test and ANOVA) were used to show the association between independent and continuous dependent variables. A Chi-square test $\left(\mathrm{Chi}^{2}\right)$ was used to test the associations between two classified variables.

\section{Results}

First, we describe what kind of approach the missionaries used regarding the local people and local cultures in their writings. It can be assumed that the attitude towards the local people will change in a more positive direction with the passing of time from the 1940s to the 1980s, while gender and regional differences (the area where missionaries worked) will be minor.

The data gives an overview of the types of people that the missionaries gave a voice to in their writings. In a total of 118 writings, missionaries dealt with different professions, as seen in Table 1 below.

TABLE 1. Local people's vocations in missionaries' writings $(\%) ; \mathrm{n}=118$.

\begin{tabular}{|l|l|l|}
\hline & $\mathrm{n}$ & $\%$ \\
\hline Farmer & 38 & 32 \\
\hline Hunter or nomad & 26 & 22 \\
\hline Teacher & 20 & 17 \\
\hline Worker & 11 & 9 \\
\hline Merchant & 9 & 8 \\
\hline Officer/civil servant & 8 & 7 \\
\hline Health care & 6 & 5 \\
\hline TOTAL & 118 & 100 \\
\hline
\end{tabular}

A third of the writings dealing with peoples' vocations describe farmers. Of these, three quarters were written by missionaries in Africa. The second most common were hunters or nomadic people $(22 \%)$. These writings came almost totally from Africa. Third were teachers (17\% of all writings), split equally between Africa and Asia.

In their writings, missionaries clearly describe the people among whom they worked or the people they identified with, such as teachers. In light of the results above, one could argue that missionaries did not want to emphasize the distance between themselves (as foreign and Western

\footnotetext{
${ }^{17}$ Pertti Alasuutari, Laadullinen tutkimus, Tampere: Vastapaino 2011; Jari Eskola and Juha Suoranta, Johdatus laadulliseen tutkimukseen, Tampere: Vastapaino 1998.
} 
missionary workers) and local people (others). Their reports are 'from where the people are' more than from the high society.

Another interesting question is whether and what missionaries reported about the ruling powers. The result is compiled in the next table.

TABLE 2. References to ruling power in the writings of the missionaries (\%); $\mathrm{n}=144$.

\begin{tabular}{|l|l|l|}
\hline & n & \% \\
\hline Authorities (state, public) & 79 & 55 \\
\hline Chieftain/popular leaders & 35 & 24 \\
\hline Military persons & 18 & 13 \\
\hline Leaders of independence movements & 7 & 5 \\
\hline Party politicians & 5 & 3 \\
\hline Total & 144 & 100 \\
\hline
\end{tabular}

When missionaries reported on people who are in power, they most commonly told about state and municipal authorities. Almost half of the writings (46\%) with that kind of reference were from the Far East, while 18 percent came from the Near East. The writings in which chieftains or popular leaders appeared were mostly from Western (74\%) and Eastern (16\%) Africa. The Far East (28\%) and Western Africa (44\%) were the regions with the most writings concerning military persons. Descriptions of local circumstances and political situations are reflected in the writings, but the missionaries seem to have distanced themselves from local politics and did not comment on the ruling powers.

Next we will present the results that describe how much and what Finnish missionaries reported about cultural, societal, religious, and geographical issues. The results are illustrated in Figure 2. 
FIGURE 2. Categories of cultural, societal and religious issues.

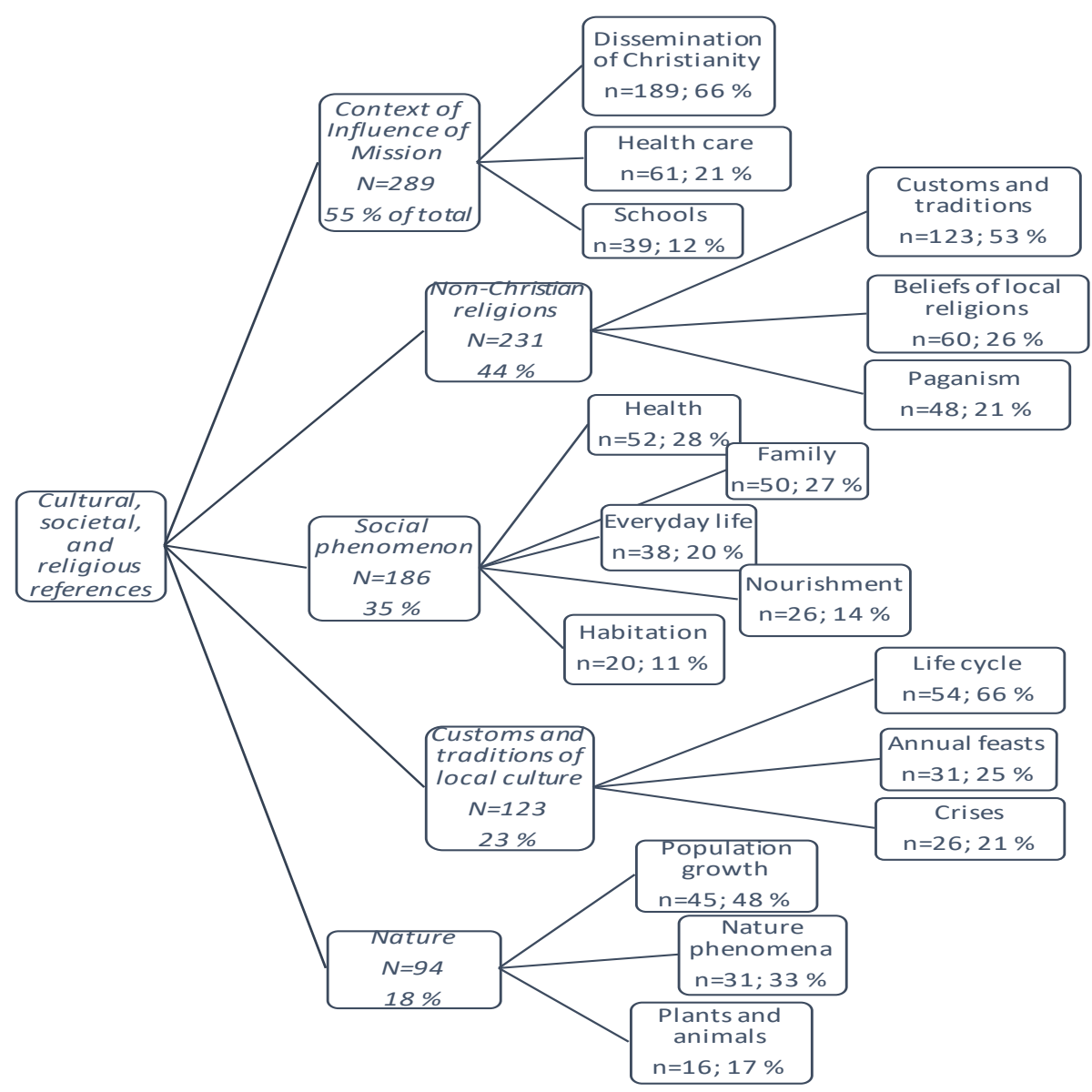

The category Context of influence of mission refers to places and contexts where the gospel was preached to people. Considering this, it is quite natural that as many as 55 percent of all writings included such references. Of these, the majority (66\%) did not specify details; the missionaries told only about the dissemination of Christianity without specifying the context. Health care was the second most $(21 \%)$ common context, and the third was educational work in schools $(12 \%)$.

Outside the Figure 2 another interesting question is how much the aforementioned writings (dealing with the context of influence of mission) talk about mission work and the Christian church. According to the results, only 16 percent $(n=66)$ of the writings include references to the church and missions. If we assume that the writings reflect the reality where missionaries worked, this result demonstrates a kind of sensitivity on the part of the missionaries. Coercive methods, or pressing on one's views, seem not to have been the approach of Finnish missionaries. Or alternatively, missionaries distinguished between social work and preaching of the Word.

Of all writings, 44 percent deal with Non-Christian religions. Slightly more than half of these $(53 \%)$ deliberate on the customs and traditions of local religions, which were foreign to missionaries. The rest of the scriptures consider beliefs (26\%) and paganism (21\%) as a phenomenon. Looking at the missionaries' writings that deal with non-Christian religions from the perspective of theology, it turns out that most issues belong to the field of Practical Theology, followed by Dogmatics (Systematic Theology) and Religious Studies. This denotes that Finnish missionaries had more of an interest in reporting how foreign religions were practised than what they taught. 
The content of descriptions of local religions is presented above, but to what extent were they described? Our data reveals that out of all writings where local religions are mentioned, 67 percent $(n=156)$ had very few references to local religions and 24 percent $(n=56)$ included some references. Only nine percent $(n=21)$ had numerous references. The result leads us to conclude that, although local non-Christian religions are present in 44 percent of all writings, their role is rather marginal.

About one third $(\mathrm{n}=186 ; 35 \%)$ of the writings of the Finnish missionaries were related to a Social Phenomenon. Issues related to health (28\%), family (27\%), everyday life (20\%), nourishment $(14 \%)$, and habitation $(11 \%)$ were also dealt with. It seems that Finnish missionaries were concentrated on supporting local people in their everyday life by emphasizing health care issues, family life and daily chores. Overcoming diseases was one of the biggest challenges of missionary work, and to overcome it, dissemination of information among families about daily routines was an important tool.

The next category, Customs and traditions of local culture, has 123 occurrences (23\%). The writings included in this category mostly introduce local customs around the lifecycle $(66 \%)$, such as birth and initiation rites. Annual feasts and holidays appear in 25 percent of the material. The crises of local cultures were present in 21 percent of the writings dealing with their customs. Nature-related writings were the smallest category $(\mathrm{n}=94 ; 18 \%)$. The most dominant theme was population growth (48\%), and the second one was natural phenomena (33\%). Plants and animals were described in only $17 \%$ of the writings.

FIGURE 3. Attitudes towards local people and local culture. Averages in different decades. Scale 1 $=$ unfavourable, $2=$ neutral, 3 = approving, 4 = favourable $(\mathrm{N}=526)$.

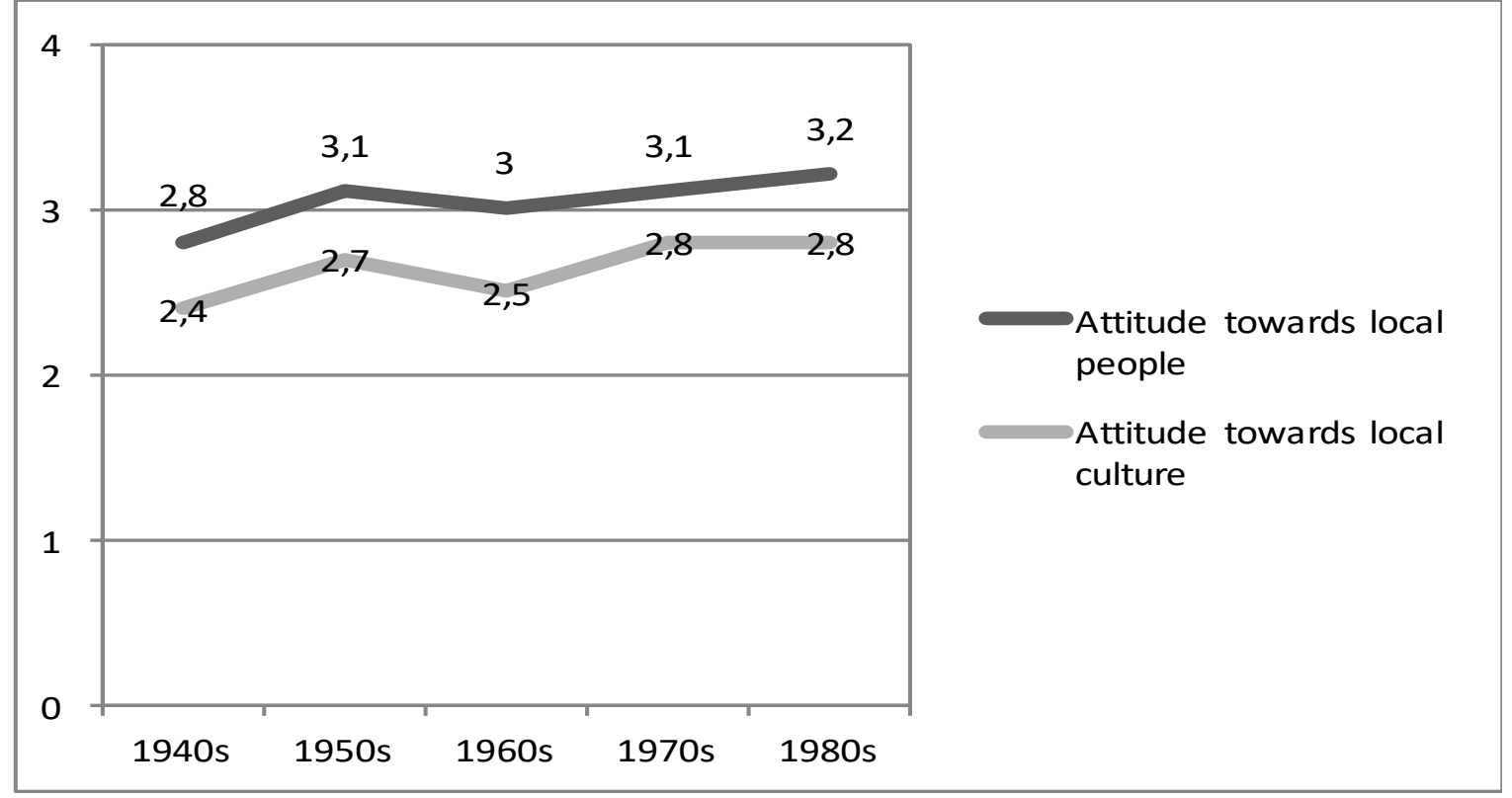

For the most part, missionaries' attitudes towards local people were approving; only in the 1940s was the average slightly less than accepting. In time, their attitudes towards local people became more positive, yet the change is not statistically significant. Concrete examples can be found in our data.

Changes in attitudes towards local people and cultures can be perceived in the use of terms like 'pagan' and 'paganism'. Out of all articles written in the 1940s, 38 percent include references to non-Christian people (those not converted to Christianity) as pagans and their religion as paganism. Pagan leaders were slaves of the devil' who worked against the missionaries. 
But paganism is still very strong in this area; the most famous witchdoctor works against us, and 'the devil's slaves' are still today engaged in such atrocities that one prefers to remain silent (LS 1946/2:2324, from Angola)

By the end of the 1950s, the use of the terms 'pagan' and 'paganism' started to gradually decline. In the 1950s they were found in 26 percent and in the 1960s in 14 percent of the articles. Even when the term 'pagan' is used, people are depicted in positive terms:

The Rector, as well as other non-Christians, seemed to be real outstanding individuals among pagans ... they left a good feeling in the heart, even though we were sitting under ancestral images and the red lamps were burning (LS 1967/4:10, from Taiwan).

In the 1970s, such terms were found only in 2 percent of the articles and in the 1980s they were missing.

The attitude of missionaries towards local cultures varied between neutral and approving (Figure 3). Like attitudes towards people, attitudes towards local cultures did not substantially change with time, even though positivity certainly increased a bit.

The following two examples from our data prove that strange customs were accepted as part of a different culture. For example, reasons for poor school performance were explained by poverty, not in terms of people (i.e. whether they were Christian or not) or their culture or religion. Parallel with Finns, the difference was said to be due to outer circumstances. By comparing local conditions and Finnish circumstances, the writer quoted below tries to make her readers understand the local people and her work among them as a teacher.

If we were actually born and raised in a small mud house, which barely has - if it has at all - furniture, not to mention a bookcase or shelves, and where in addition to mud and open dirt ditches and flies a child has nothing more to explore, I doubt whether we could actually show very strong interest in learning and what is happening elsewhere in the world (LS 1975/5: 16, from Pakistan).

In the 1980s, there was an effort to give a voice to local people in the form of interviews where they themselves told about their life and culture. More academic and analytical descriptions of local cultures and religions can be found. Terms like 'non-Christians' and 'old traditional customs' and more academic terms like 'animism' are more common in the last decade of our research period. There was an effort to describe how people understood Christianity from their own cultural background:

Religious practice in Africa was life-affirming and preserving. Many rituals were designed to safeguard life and fertility and to protect people against the evil forces of destruction ... People were accustomed to sacrifice and worship. Christianity is thus seen not to compensate for the general revelation they already had, but rather to complement it (LS 1984/13: 6, from Tanzania).

Gender differences were examined by using Student's t-test. Women's writings about local people $(\mathrm{M}=3.3 ; \mathrm{s}=.89)$ were more favourably disposed than men's $(\mathrm{M}=2.8 ; \mathrm{s}=.92)$ writings. The difference was statistically very significant $(\mathrm{t}=-5.51 / \mathrm{df}=524 ; \mathrm{p}=.000)$. Also, concerning the local culture, women $(\mathrm{M}=2.8 ; \mathrm{s}=1.01)$ wrote more positively than men $(\mathrm{M}=2.5 ; \mathrm{s}=.99)$. The difference was statistically significant $(\mathrm{t}=-2.51 / \mathrm{df}=524 ; \mathrm{p}=.012)$. Other findings support these gender differences as well. Gender differences also appear in the style and form of writings women and men report on the whole. Less than half (43\%) of men's writings were feature-style texts describing local culture, compared to more than half (54\%) for women. Women also posted descriptions of their own work (15\%) slightly more than men $(12 \%)$. 
Regional differences (i.e. the area where missionaries worked) are illustrated in Figure 4. We do not report the differences between individual countries but regional differences, comprising four larger areas.

FIGURE 4. Attitudes towards local people and local culture according to regions. Scale $1=$ unfavourable, $2=$ neutral, $3=$ approving, $4=$ favourable $(\mathrm{N}=526)$.

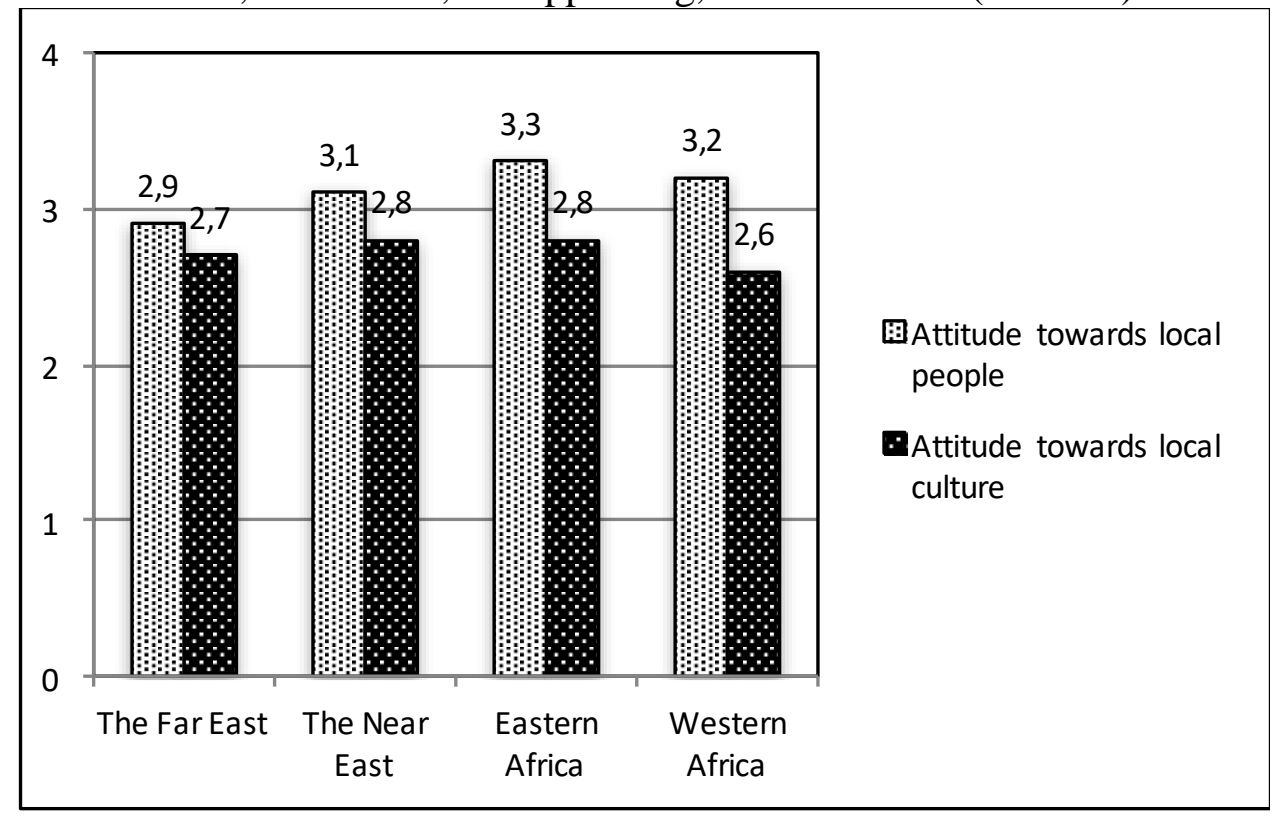

Missionaries' writings reflect different attitudes towards local people, depending on the area of their mission field $(\mathrm{F}=3.32 / \mathrm{df}=3 ; \mathrm{p}=.02)$. Group differences are found between the Far East and Eastern Africa $(\mathrm{p}=.004)$, and the Far East and Western Africa $(\mathrm{p}=.02)$. There were no statistically significant regional differences in attitudes towards local cultures.

Why did missionaries report in significantly different ways about Far Eastern people than people living in Eastern or Western Africa? One explanation is that Finnish missionaries operated much longer in Africa than in the Far East. They arrived in South-West Africa in 1870 and China in 1902. ${ }^{18}$ The longer they were together, the more mutual understanding developed between missionaries and local people. Another explanation is that right from the beginning, missionaries faced more resistance and disinterest in the Far East than in Africa. This trend, which has continued, may have influenced missionaries' reports about the local people.

In some cases, the local culture intrigued and even aroused admiration in Finnish missionaries, as the next citation reveals. Even in the 1940s, the representatives of a strange religion and culture were described in a respectful and appreciative way, even when they challenged the missionary's own way of life. The missionary's personal interest in philosophy also may have affected his attitudes towards the local people.

It is not suitable for a missionary to approach such men [Buddhist monks] from above ... I have met monks beside who I have felt myself small and inferior ... These men may have self-discipline, which makes me ashamed of myself ... For such truth-seekers, must be given credit for their serious quest for wisdom and truth (LS 1947 / 7-8. 106-107, from China).

\footnotetext{
${ }^{18}$ Uno Paunu, Suomen pakanalähetystoimi 2. Suomen lähetysseura vuosina 1859-1876, Helsinki: Suomen Lähetysseura 1909; Matti Peltola, Sata vuotta suomalaista lähetystyötä 1859-1959 II. Suomen lähetysseuran Afrikan työn historia, Helsinki: Suomen Lähetysseura 1958; Pekka Lund, Kuilun reunalla. Suomen Lähetysseura Kiinassa 1926-1929, Helsinki: Suomen Lähetysseura 2006.
} 
According to Löytty ${ }^{19}$, framing otherness can have both positive and negative consequences. The identification of otherness is positive if it is followed by an increase in equality and fairness, but when it instead highlights differences and negative estimations of other people, the consequences of otherness are negative.

Next we will consider if missionaries dealt with their own culture and local culture together or separately. It has been asked, how did the missionaries write about local culture? Did they refer to Finnish or Western culture, or probably both, or did they tell only about the local culture without making cultural comparisons? Cultural comparisons were not very common, since the local culture was mentioned in relation to other cultures in only 132 writings, or 25 percent of the total.

FIGURE 5. Descriptions of local culture together with Finnish and Western culture from the 1940s to $1980 \mathrm{~s}(\%) ; \mathrm{n}=132$.

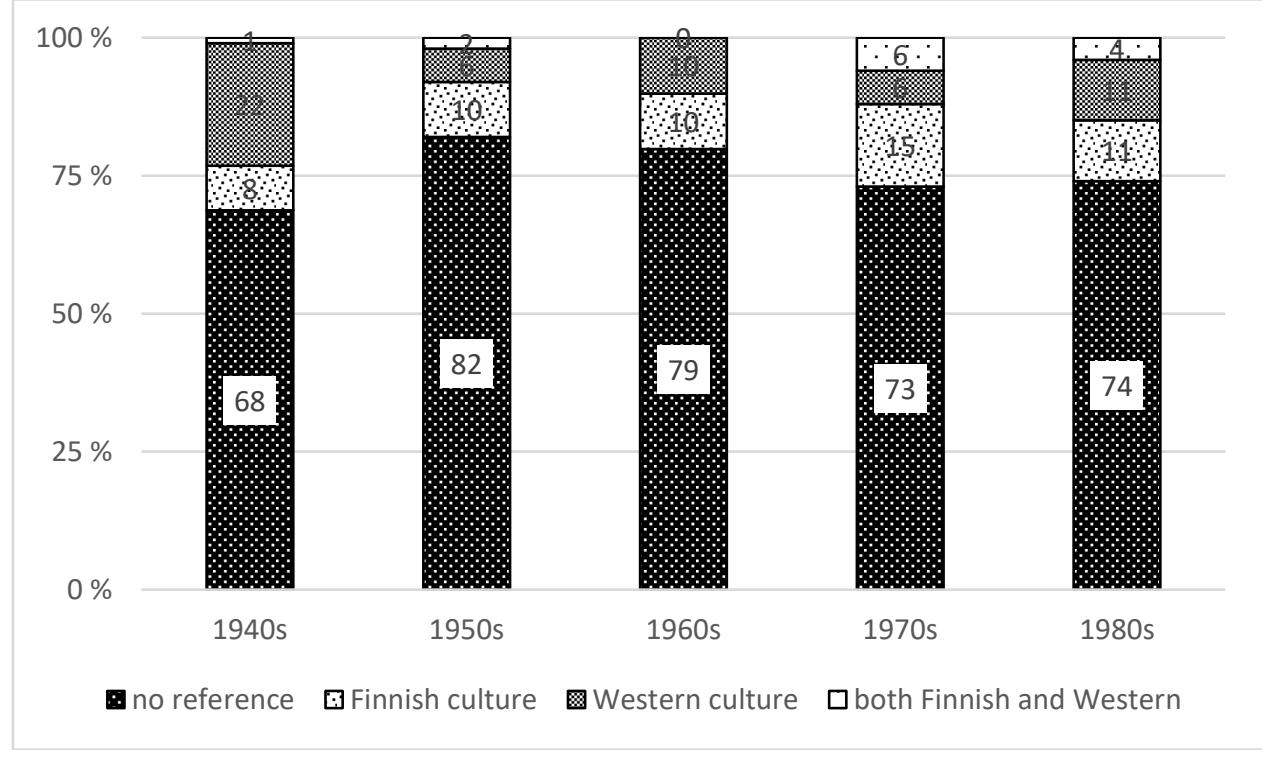

Figure 5 reveals that the missionaries normally did not make cultural comparisons. Most often, local cultures were described independently, such as they were, not in relation to Western or Finnish civilization or Christianity. Attention must be drawn to one little detail, however: the relatively large proportion of references to Western culture in writings from the 1940s. This may be explained by the Finnish post-war circumstances. After the Second World War, Finland identified itself with and directed its aspirations towards the Western world, which represented the desired political and cultural sphere where one wanted to belong. Consequently, those same attitudes were also applied to those cultures where they worked.

No gender differences were found. The region of the mission field was one explanatory factor $\left(\mathrm{Chi}^{2}=21.05 / \mathrm{df}=9 ; \mathrm{p}=.012\right)$. Writings that were sent from Eastern Africa had more comparisons to Finnish culture.

FIGURE 6. Cultural comparisons in missionaries' writings according to region (\%); $\mathrm{N}=520$.

\footnotetext{
${ }^{19}$ Löytty, 'Toiseus'.
} 


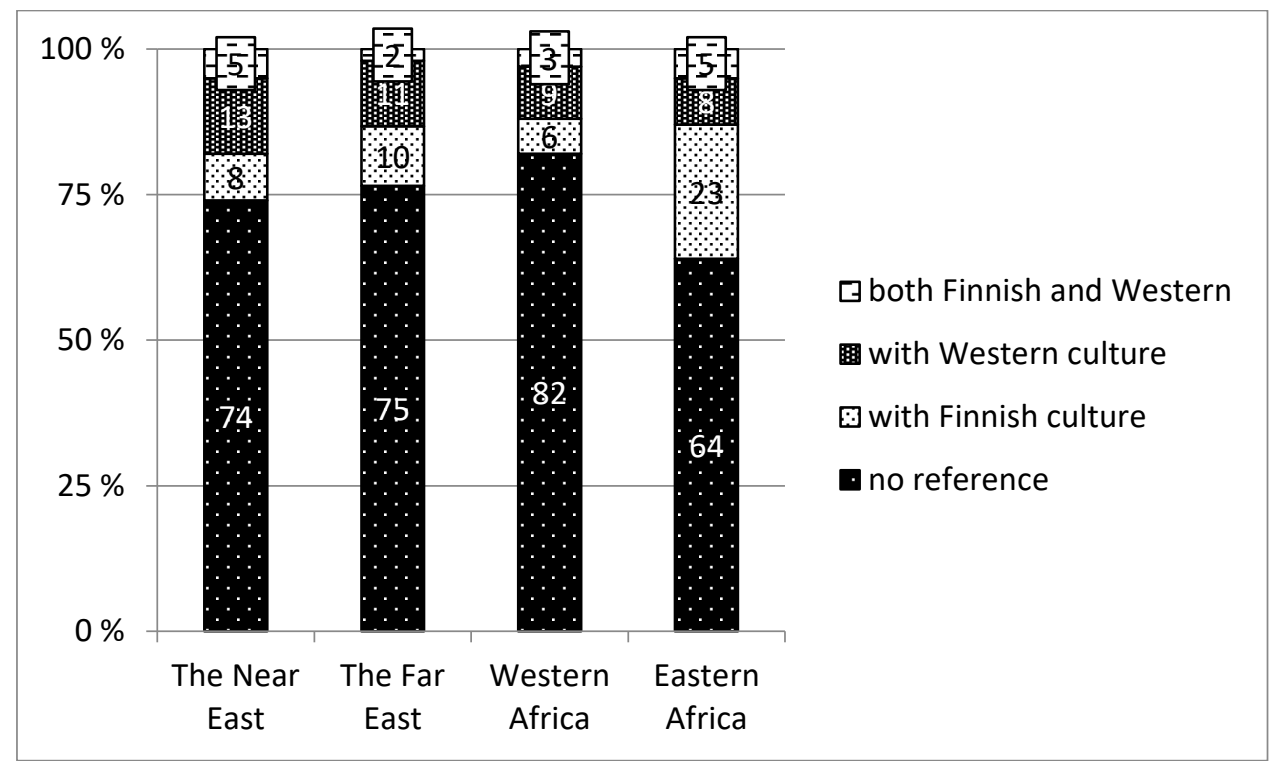

Compared with other regions, the high percentage of writings from Eastern Africa relating it to Finnish culture is interesting. It may be explained by the fact that in Tanzania, for example, in several parts of the country the church was well established and many missionaries worked in the areas of education and health care. The African setting was reflected in the light of the previous working experiences in Finland. Furthermore, this may also tell about the writers' efforts to relate the communicated information with the recipients' own setting where the readers had personal experiences.

From the perspective of otherness, the results shown in Figures 5 and 6 reveal a rather neutral attitude to other cultures. In their writings, missionaries primarily described local cultures such as they were without any hierarchical approach.

The way in which the missionaries saw the role of the recipients of their writings strengthens the interpretation above: in 77 percent $(n=407)$ of all writings, the role of the recipients was to receive information, and only in 23 percent $(n=119)$ did missionaries appeal to recipients to support missionary work. This is to say, the missionaries stressed their role as informants more than promoters.

Aside from the comparisons as we have reported thus far, a further insight into otherness surfaced in how foreign (or in this case, local) cultures are reflected in the writings. Local cultures can be seen as full of difficulties and problems, or capabilities and potential for future development. Figure 7 illustrates the manner in which the missionaries described local cultures.

FIGURE 7. Manner of description of local cultures (\%); $\mathrm{N}=520$. 


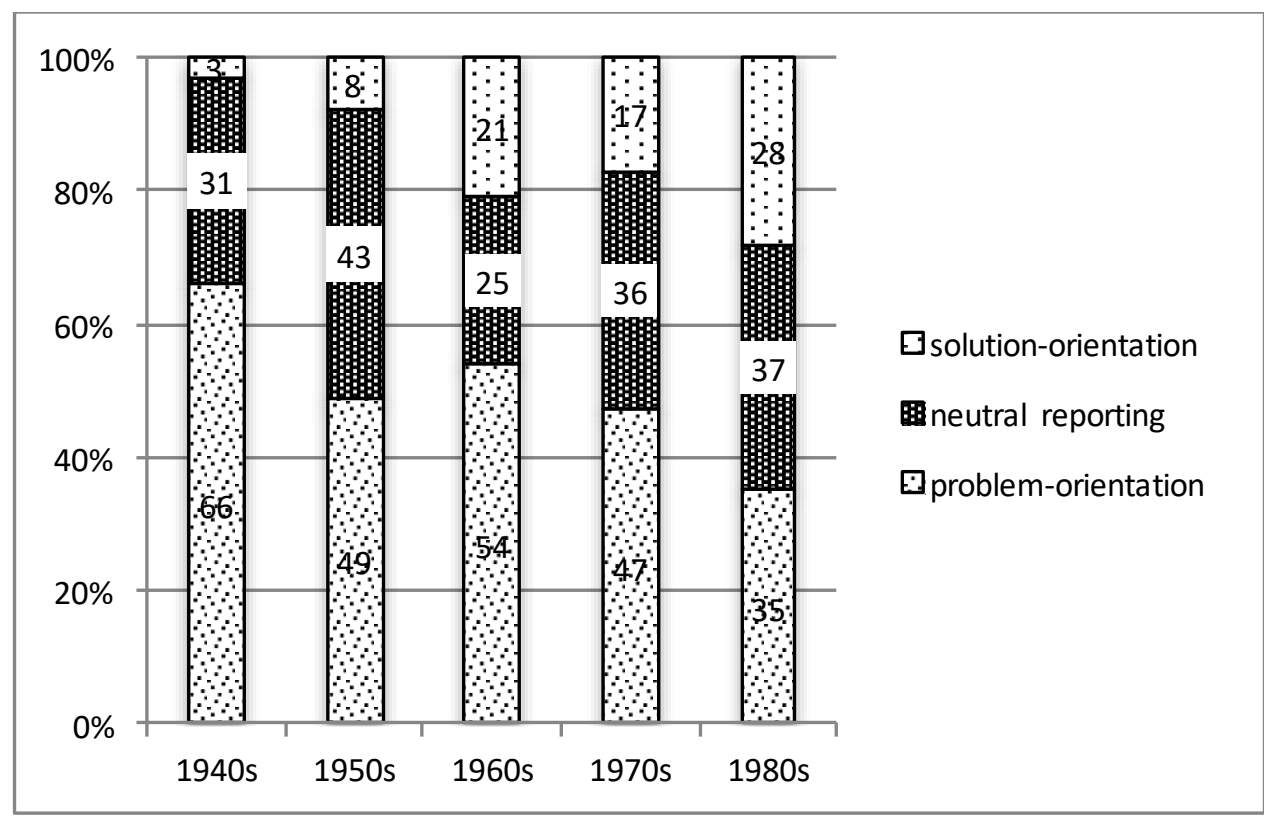

The result in Figure 7 clearly shows $\left(\mathrm{Chi}^{2}=40.85 / \mathrm{df}=8 ; \mathrm{p}=.000\right)$ that highlighting the problems of local cultures in the writings of missionaries decreased over time, excluding the 1960s, which deviate from the trend. At the same time, the amount of the solution-oriented writings increased. Regarding the proportion of neutral reports, there were only marginal changes over time.

The increase in solution-oriented descriptions is very interesting. It reveals that missionaries did not view local people and circumstances like as outsiders. They aimed to depict themselves as being part of the local setting, willing to see and develop solutions to problems together with the local people. Seeing them as other decreased as time went on.

Figure 8 shows regional differences in describing local cultures.

FIGURE 8. Manner of describing local cultures according to region (\%); $\mathrm{N}=489$.

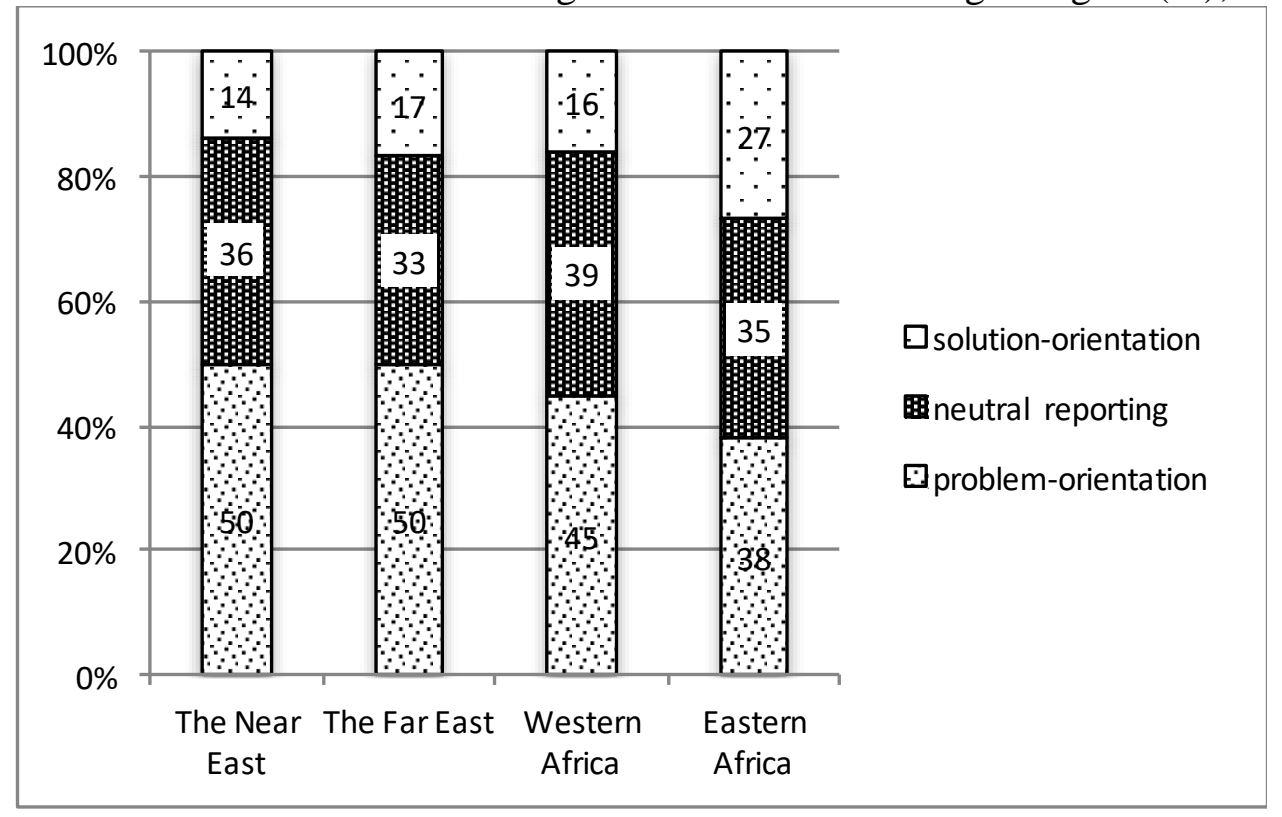

The results are quite consistent between the Near East, Far East and West Africa. East Africa differs from the other regions since less problem-oriented but more solution-oriented writings were written there. The differences were not statistically significant. A question arises whether the fairly stable 
political conditions in Eastern Africa may partially explain the difference, with outer circumstances providing a setting that made it possible to find solutions to the prevailing problems.

\section{Conclusions and Discussion}

Missionaries' writings tell about the grassroots organizations they worked with in varied cultures in different parts of the world. Their main aim has been to give information to supporters and interested parties about their mission work. However, it is likely that, apart from the guidelines of the mission journal, the choice of themes, focus and approaches also reflect the missionaries' own interests. Attitudes towards local cultures take a more positive course over time, but the changes are minor, often not statistically significant. Gender differences are clear. Female missionaries reported more favourably about foreign people and cultures than men, which is in line with previous research on the respective gender differences. ${ }^{20}$

Three major conclusions can be drawn from the results. First, from their own ideological, humane and philanthropic starting points, missionaries have found it easier to accept local people than local cultures. Man was made in the image of God; accordingly, s/he is precious and unique, even if not a Christian and not sharing the same values and belief system as the missionaries. Local cultures, on the other hand, may be perceived to have strange habits that can corrupt human beings. For this reason, the approach of missionaries regarding local cultures has been more reserved than their attitudes towards local people.

The significant geographical differences in attitudes to local peoples need further elaboration. The positive attitudes towards people in the Near East may be explained by the positive view of Jews in the society's mission ideology. The contact hypothesis could be a useful tool to interpret the attitudinal differences between the Far East and Africa. Studies on interreligious contacts reveal that the size of a religious group is correlated with a decrease in negative attitudes towards other groups. The bigger the group and the number of contacts, the more positive attitudes are. The quality of contact also reduces negative attitudes, regardless of relative group size. ${ }^{21}$ Finnish missionary work has also had a longer history and more missionaries in Africa than in the Far East. During the study period, churches were small and Christians were in the minority in the Far East, whereas for example in South-West Africa and Eastern Africa churches were well established and grew rapidly. It was easier for the missionaries to find their niche in Africa than in Asia.

Secondly, the leap in the cultural and political climate from the 1940s to the 1950s was quite big. Struggles for independence started in the late 1940s and early 1950s, both in East and South-West Africa. The 1950s and 1960s were turbulent years in many ways, and missionaries had to start to change their attitudes towards local cultures and leadership. For some, this may have been a painful process, but according to the results missionaries seem to have managed to change their attitudes.

Thirdly, in the 1960s the attitudes of missionaries towards local cultures were more negative than during other decades, except the 1940s. All in all, in the 1960s there were less writings than in other decades. Therefore, the probability of random errors is greater. The form and style of the writings may also explain the result. In the 1960s, missionaries produced several feature-style writings, which emphasized the presence of the local culture. During the 1960s, the proportion of those writings was 73 percent, while it was less in the previous decades $(21 \%$ in the $1940 \mathrm{~s} ; 50 \%$ in the 1950s). An explanation for the focus on local culture may be found in that in the 1960s, many African nations became independent. This also meant local governments and people turning

\footnotetext{
${ }^{20}$ See e.g. Andrej Kokkonen, Stefan Dahlberg, Eelco Harteveld and Wouter van der Brug, 'Group Gender Composition and Tolerance of Immigrants Rights', European Sociological Review 31/1 (2015), 65-76.

${ }^{21}$ Agnieszka Kanas, Peer Scheepers and Carl Sterkens, 'Interreligious Contact, Perceived Group Threat and Perceived Discrimination: Predicting Negative Attitudes among Religious Minorities and Majorities in Indonesia', Social Psychology Quarterly 78/2 (2015), 102-126.
} 
towards their local cultural heritage for inspiration in various fields in society, the church included. Changes also took place in the theological realm. In the late 1960s, Vatican II presented new views on missiology. For example, local music was utilized in the liturgy (Misa Criolla, Missa Luba). These views were reflected also on the Protestant side. Missionaries were called to accept the contextual expressions of Christianity and to perceive local church workers as equal partners in both spiritual and practical matters. By the 1970s, the cultural 'renewal' of going back to the roots had stabilized and found its form. Missionaries' writings reflect their adaptation to the new cultural climate.

The majority of the writings are descriptions of local cultures and people without any comparisons to Western - or, more specifically, to Finnish - culture. During the study period, the othering of the people among whom the missionaries worked had decreased. One could talk about increasing cultural relativism in missionary writing. Furthermore, the decrease of the problemoriented approach to local cultures bespeaks an effort towards a more inclusive understanding of local contexts and viewing people in a positive light. The longer missionaries worked in a particular country, the more concrete ways of solving problems and working patterns were developed. The missionary was not a short-term visitor, but had changed from an observer into an active subject. Together with the shifts in attitudes, these changes can be interpreted to indicate an effort towards a positive interpretation of otherness.

Our pioneering longitudinal and quantitative analysis of missionary writings reveals the possibilities of quantitative methods for detecting global and local changes in Christian missions. Seeing qualitative and quantitative analysis as a continuum complementing each other opens new approaches to mission studies. 